\title{
Transparency of law making and fiscal democracy in the Middle East
}

\author{
LOBNA M. ABDELLATIF, Ph.D.* \\ MOHAMED ZAKY, Ph.D.* \\ MOHAMED RAMADAN, Ph.D* \\ JAD MAZAHREH, MSc* \\ IBRAHIM ELGHANDOUR*
}

Article**

JEL: H11, H61, H62, H64, H72

https://doi.org/10.3326.pse.43.1.5

\footnotetext{
* The authors would like to thank Ms. Nouran Adel for the excellent research assistance she provided and the two anonymous referees for helpful comments on the paper.

Funding: World Bank provided a travel and accommodation grant to the affiliated authors to attend the Public Sector Economics (PSE) conference "Fiscal Openness: Transparency, Participation and Accountability in Fiscal Policies" held in Zagreb on 26 October 2018.

${ }^{* *}$ Received: October 16, 2018

Accepted: January 7, 2019
}

A previous version of this paper was presented at the conference "Public Sector Economics 2018 - Fiscal openness: transparency, participation and accountability in fiscal policies" organized by the Institute of Public Finance, International Budget Partnership and Friedrich-Ebert-Stiftung in Zagreb on October 26, 2018.

\section{Lobna M. ABDELLATIF}

Senior Public-Sector Specialist, Governance Global Practice, World Bank, seconded from Cairo University 1818 H street NW, Washington DC - 20433, USA

e-mail: lahmed@worldbank.org

ORCiD: 0000-0002-0677-7684

\section{Mohamed ZAKY}

Lecturer, Cairo University, 1 Gamaa Street, Giza, Egypt

e-mail: m.zaky@feps.edu.eg

ORCiD: 0000-0002-9260-9600

\section{Mohamed RAMADAN}

Research and Development Adviser, Central Agency for Public Mobilization and Statistics of Egypt, 3 Salah Salem St., Nasr City, Cairo, Egypt

e-mail:moh_ramadan@icloud.com

ORCiD: 0000-0001-6315-4996

\section{Jad MAZAHREH}

Senior Financial Management Specialist, Governance Global Practice, World Bank,1818 H Street, NW Washington, DC 20433 USA

e-mail: jmazahreh@worldbank.org

ORCiD: 0000-0001-5830-2325

\section{Ibrahim ELGHANDOUR}

Research Analyst, Governance Global Practice, World Bank,1818 H Street, NW Washington, DC 20433 USA e-mail: ielghandour@worldbank.org

ORCiD: 0000-0001-5720-6868 
Abstract

Fiscal democracy is the capacity of the legislature to make budgetary choices in response to the emerging needs of citizens. This study indicates that, in Middle Eastern countries, there are specific limitations to fiscal democracy in the process of law-making: most notably the lack of attention to financial impact assessments (FIAs). Without systematic FIAs, mandatory out-of-budget allocations are inadvertently included in public spending, as they do not require parliamentary approval within the regular budgeting process. The low level of effective citizens engagement in the process of law-making worsens the situation. Budgetary decisions are not well informed by national priorities and preferences. This study utilizes the dataset of the Open Budget Index (OBI) to measure the quality of the law-making process of the budget law in a sample of Middle Eastern countries. The study concludes with recommendations on mapping the law-making process to increase budget transparency.

Keywords: fiscal democracy, mandatory spending, Financial Impact Assessments, citizens' engagement, law-making process, budget transparency

\section{INTRODUCTION}

Parliaments' capacity to respond to the emerging needs of citizens by utilizing budgetary resources and reallocating public expenses is a key pillar of the democratic practices in modern economies. In this regard, fiscal transparency, whereby budgetary information is available for public discussions and effective communications with citizens, is a critical factor that empowers parliaments to make informed budgetary decisions (Alesina and Perotti, 1996; Alt and Lassen, 2003; Shah, 2007; Harrison and Sayogo, 2014; Williams, 2015; Zuccolotto and Teixeira, 2014; Sarr and Friedman, 2016; Renzio and Wehner, 2017). Hence, a lot of interest has been directed to the determinants of enhanced fiscal transparency.

Budget classification, the timely availability of budget documents, the openness of the discussion process to the public and the strength of the roles of supervisory agencies are among the factors included in the Open Budget initiative through its survey to assure fiscal transparency (IBP, 2017). Countries in the Middle East and North Africa (MENA) region are part of this worldwide movement towards fiscal transparency, legislatures' empowerment, openness and citizens' engagement.

However, a critical factor that restricts fiscal transparency in the MENA region is the considerable mandatory out-of-budget expenditures. They are mirrored by expenses that are not voted on, as they do not require parliamentary approval within the annual budgeting process, e.g. wages and salaries, pensions, debt service, etc. Such expenditures reduce budget flexibility and responsiveness to the dynamics of development. This is mostly attributed to law-making legacies that accumulate over time, constraining the discretion of parliaments to respond to emerging needs (Streeck, 2010). 
Conducting comprehensive Regulatory Impact Assessments (RIAs) includes reviewing whether proposed policies match national priorities as well as whether they are affordable and meet value for money criteria is essential in protecting budget flexibility. Given the importance of this topic, the World Bank produced the Global Indicators of Regulatory Impact Assessment Governance to highlight international efforts in this direction (World Bank, 2016). Most of the work on RIAs in the MENA region is still directed to business, trade and the private sector. The financial impact of law-making is touched upon but has never been the focus of discussion.

This study contributes to the existing literature by introducing a new measure of fiscal transparency that investigates the budget law through a RIA lens. It provides a measure of the extent to which governments interact with the public across the life cycle of the budget process, evaluating the mechanisms to do so, and efforts made to solicit the results of public consultation. Further, the study sheds light on the dependency relationships between the diverse dimensions of fiscal transparency by directing attention to the notion of effective transparency.

This study aims to raise awareness about a budget law as the financial framework that reflects the quality of the process of law-making. Specifically, it seeks answers to three questions: (i) what is the level of fiscal discretion the parliaments in MENA have over the allocation of budget resources, (ii) how effective is the financial regulatory impact assessment of law-making in controlling the financial impact of the new policies on the budget, and (iii) what are the features established in the Budget Law-making process to control the impact of policies introduced in the budget.

The study focuses on the MENA region with closer review of three country case studies; Egypt, Jordan and Tunisia, to provide an in-depth perspective on current practices. The analysis remains applicable to other countries and regions. Two of the case studies, Tunisia and Egypt, are "Arab Spring" countries where mass protests called for inclusiveness, openness and fairness. The call spread quickly to a few countries, among which was Jordan, before eventually impacting all countries in the region. The three selected countries have pioneered parliamentary practices within MENA, some of them stemming from the first half of the last century. With the advent of the Arab spring, they also witnessed changes in legislation and amendments to their constitutions to provide more authority to parliaments and a wider opening for the engagement of civil society towards an increased voice for citizens and transparency (OECD, 2013). For the case studies, the analysis makes use of first-hand data collected through in-depth and structured interviews with key stakeholders, including members of the parliaments, former ministers, senior executives in Ministries of Finance (MoF) in Egypt, Jordan and Tunisia in addition to secondary data, analysis and reviews and content analysis of country related documents. 
The study is structured into four sections. Section one presents the increasing footprint of public finance and relates it to fiscal decision-making. Section two provides information on conducting financial impact assessments. In section three, we establish the relationship between RIA transparency with fiscal transparency. Section four concludes with recommendations.

\section{SECTION I: FISCAL TRENDS AND FISCAL DEMOCRACY 2.1 FISCAL TRENDS}

Public finance constitutes a large magnitude of GDP across all regions in the world. As figure A1 indicates, the percentage of the gross debt to GDP has been always high. Given its size and potential impact, the formulation and execution of the budget should be carefully examined. Public finance suffers, generally, from the common pool problem: it is not always possible to establish a one-to-one correspondence between who pays and who gets the benefit. Additionally, if revenues do not cover expenses, there are several options for financing the public debt. Along with the cost comes the impact on intergenerational welfare through debt servicing and inflationary impacts, which imply a lower capacity to finance future service provision. Therefore, the parliamentary process of enacting the budget, in addition to the openness of this process to the public, has received a lot of attention as it determines the distribution of the current impact among different societal groups as well as among them and the future generations.

MENA countries experience the same international trends of growing public finance imbalances. Expenditure is growing at a higher pace than revenues, leading to increases in the financing gap (figure A2). Table A1 confirms that the growing deficit is not limited to MENA non-oil countries. The oil economies in MENA share similar experiences with a narrowing of fiscal space following the collapse in oil prices since 2014. This has led to greater attention to financial impacts when new policies and legislation are being proposed.

\subsection{FISCAL DEMOCRACY}

The phenomena of chronic budget deficits and rising public debts are a common symptom of explosive mandatory entitlements. By definition, mandatory spending is composed of budget outlays that are controlled by law other than appropriation acts (Austin and Levit, 2012). Over time, entitlement programs become more expensive per beneficiary and may be coupled with increased number of beneficiaries, thereby increasing the burden on available fiscal resources. For the first time in the history of the U.S., program entitlements exceeded government revenues in 2009. That is, every dollar of revenue had been committed even before the new Congress first walked through the Capitol doors (Steuerle, 2016). In 2010, Eugene Steuerle and Tim Roeper introduced the index of fiscal democracy to highlight the reduction in the flexibility of fiscal resources of the U.S. because of accumulated policy legacies that occupy a large share of the Federal tax revenue and leave limited room for discretionary expenditures. Streeck (2010) applied the fiscal democracy index to Germany with a few adjustments given the fact that 
there's no formal distinction between mandatory and discretionary spending in Germany (i.e. legislators vote on the entire budget). Yet, Streeck recognized at least four categories in the German federal budget, beside interest payments, that are de facto mandatory.

The idea is not new that "policy legacies" may accumulate over time, constraining the choices of elected governments and parliaments and diminishing the capacity of states to respond to emerging social problems (Streeck, 2010). The policy legacy that they inherit is carried forward by institutional commitments grounded in laws, organizations, and budgets that are more important than the preferences of individuals (Rose, 1990). From the standpoint of legislators, accumulated policy legacies in the form of mandatory programs - hinder their capacity to allocate the government revenues in a way that satisfies the current public needs. Steurele and Roeper's index measures the percentage of federal tax revenues that is not allocated to mandatory spending. A fiscal democracy index can be thought of as a measure of the extent to which yesterday's legislators dictate tomorrow's budgetary allocations.

It measures the decision space opened for legislatures to reflect public priorities through the reallocation of public spending among different sectors and policies, and willing to make hard political decisions which in many developing societies could be seen as far reaching. A fiscal democracy index is calculated as the remaining balance of the percentage of total government revenues that is devoted to paying the mandatory expenses in the form of wages and salaries and interest expenses. At the top of mandatory expenses come civil service wages and pensions and interest payments. They are out of budget decisions. Other expenses have a quasi-obligatory nature such as subsidies which have a high political profile and once enacted are extremely difficult to amend in our three country cases. They constitute part of the profile of the social contract. Therefore, we present two versions of the fiscal democracy index, without and with subsidies. Additionally, interest payments constitute part of the mandatory spending.

As shown in figure A3, the fiscal democracy index in Egypt turned to a negative number upon the addition of the subsidy component in the budget. So, in order to pay subsidies, the government must go further into debt. Accordingly, the major part of public expenditure decisions is taken out of the budget, and the fiscal democracy index in Egypt declined dramatically. Since the Egyptian revolution of January 2011 and the adverse economic and political conditions that followed, wage bills have witnessed a dramatic increase due to responses to workers' strikes and demonstrations, the appointment of temporary employees and application of the minimum wage policy. Additionally, government spending on subsidies and social benefits increased by about 1.7 times during the period 2010-2017 (figure A4). On the other hand, tax revenues declined because of political and economic instability and decreased economic activity. Egypt's fiscal imbalances have subsequently worsened as interest payments have increased more than fourfold during the same period: clearly an unsustainable situation. 
This pattern also applies, albeit less acutely, to Jordan and Tunisia. Fiscal consolidation efforts in Jordan have started to yield positive results. However, subsidy expenditures constitute a persisting issue. The government wage bill in Tunisia is relatively high, taking up more than 60 percent of government revenues and 50 percent of expenditures. The wage bill to GDP ratio has grown by 4.0 percentage points between 2010 and 2017, and reached 14.7 percent of GDP in 2017, excluding $0.4 \%$ of GDP in tax credits given to public employees. The wage bill to GDP ratio is expected to reach 13.9 percent of GDP in 2018. In comparison, government spending on investment reached 5.5 percent of GDP in 2017. The expected decline in the ratio reflects an increase in the GDP growth rate and a deceleration in the growth of the wage bill resulting from a recent set of wage bill containment measures. Nonetheless, the trend of worsening composition of government expenditures may continue to lead to a cycle of wage bill increases which crowds out capital spending, with adverse consequences for spending efficiency and economic growth. Figure A4 shows the nominal growth of government spending between 2010 and 2016, with a modest growth of capital expenditures compared with spending on wages and salaries, which nearly doubled during that period. According to the Ministry of Finance, spending on civil service pay will reach around 53 percent of primary expenditures in 2018 (52.5 percent in 2017) and more than 60 percent of total revenues (excluding grants) over the same year.

To sum up, the growing fiscal deficit in MENA is attributed to the automatic increase in mandatory spending, resulting in a situation in which governments are financing their functions with debt accumulation (figure A5). In some cases, like that of Egypt, the budget experiences real challenges where almost half of the expenditure is absorbed by debt service, leaving little room for financing new calls. Having almost $90 \%$ of the revenues locked into paying for mandatory expenses, other social policies in Egypt would be financed with debt. That is to say, if in past days, some countries in the region were not concerned with the budgetary structure and fiscal trends, from now on the situation is serious enough to warrant deep assessment of any action that can be anticipated to have financial implications. Hence, parliaments are requested to scrutinize all proposed legislative acts for their budgetary implications.

\section{SECTION II: REGULATORY IMPACT ASSESSMENT (RIA)}

In this section, the study reviews practices of conducting RIAs in MENA, in a comparable context, with a special focus on conducting financial impact assessment of proposed legislations.

\subsection{PRACTICES}

Worldwide, there is a growing interest in regulatory reforms including assessing the impact of legislation on the economy at large, public finance, and the impact on different groups in society such as the business community, households and vulnerable groups. In the last three decades, regulatory impact assessment has started to be an integral part of analysis and decision-making in governments that 
are committed to increased transparency and evidence-informed policy-making. The history of regulatory impact assessment as a formal regulatory quality tool extends over more than 25 years in the OECD (OECD, 2009). In EU countries, evaluation of the effectiveness, enforceability and cost of legislation is treated as an integral part of the law-making process (Kellermann, 2008). However, the practice is still only growing worldwide and not standardized yet in many developing countries.

The quality of legislation is affected by the process of law making starting from the planning stage through promulgation and release to implementation. An overly complex regulatory framework, lack of transparency in the preparation of new regulations, plus ineffective and inappropriate application of the rules are all factors that combine to favour corruption and dishonesty.

In addition, a transparent process of assessing the impact of legislation on the economy is a key advantage of a transparent RIA process as it breaks the circuit of asymmetric information that may impact negatively the decision-making power of the affected parties. It also allows all parties to voice their opinion and defend their interests in a structured manner. Via RIA practices in many countries, the assessment studies cover the impact on public health, business environment, likely vulnerable groups, and the public sector in financial and administrative aspects. The later item relates to the cost of legislation.

The cost of legislation and the efficiency of policies embedded in it, should be investigated before any law is passed; with some exceptions, if it is related to urgent basic needs like public health and safety. The cost of legislation is critical because the budget is neither totally flexible nor perfectly fixed. This means that adding or amending policies of and approaches to the conduct of a public service would not completely replace existing ones. New policies come with an additional cost. The flexibility of the budgeting system depends on the capacity of the government to reallocate resources through prioritization, which entails frequent review of policies and hence the legal framework operationalizing them, in addition to exploring new options to increase public resources. When the budget is fully fixed, any new policy will completely displace some existing ones and some options that were previously available will be foregone. Therefore, legislation that omits a financial impact assessment should be considered to be incompletely drafted legislation that may achieve its objectives at an unjustifiable cost instead of looking for better options.

Efforts for regulatory reform including RIA, have been of interest in MENA countries for many years. The business environment, growth and job creation are top priorities. More recently, issues of inclusion and citizenship have also emerged. However, MENA achievements in RIA practices are still below international levels. The latest Global Indicators for Regulatory Governance (GIRG) for 2016 (World Bank, 2016) reveal weaknesses in activities related to conducting 
regulatory impact assessment in the Middle East and North Africa (MENA) region compared to the global average (figure A6). MENA on average has the lowest score for "no notification of promulgating laws". The notification and ability of citizens and firms to engage with governments on proposed business regulations do differ around the world; however, MENA has the lowest regional level of transparency and engagement.

The three case studies vary in their performance related to RIA. Among the highest performers in MENA comes Tunisia (table A2). It stands out in three areas of RIA: transparency in law accessibility, openness for consultation to the public, and conducting impact assessment. Egypt and Jordan also provide access to the passed primary laws. In Egypt, this facility is protected by a paywall. Additionally, Jordan has higher score in openness with the public through prior consultation during the drafting stage.

In Jordan, any new legislation should be published and communicated with the public prior to approval. But there are no obligations to include any type of assessments. With the assistance of USAID, Jordan produced draft guidelines for RIA in 2010. Organic budget law no 58 of 2008, article 4-g, stipulates that part of the General Budget Department (GBD) responsibilities is to, "give an opinion on draft legislation that has financial impact during the stages of its adoption". In practice, this is only if the PM asks for an opinion. Draft organic budget law of 2017 makes it mandatory to include a financial RIA in the medium term financial framework (MTFF).

Egypt has a long history of trying to apply RIA, starting with the establishment of the National Committee for Review of Economic Legislation by a Prime Ministerial Decree No. 1816/2004 (ERRADA, 2011). In August 2011, a specialized unit published "the Egyptian RIA Guidelines" which incorporate both the concept of the standard cost of implementing a legislation and also a simple methodology to conduct benefit-cost analysis (ERRADA, 2011). Additionally, it has the merit of recognizing the importance of consultation with the public during the process of preliminary planning for the legislation. However, the Guidelines were not adopted because of the prevailing political situation at the time and the unit was shut down in 2013. Recently, the Council of Ministers (CoM) decided to add to the organization structure of each government agency a new unit to assess the impact of its proposed legislation before passing them to the CoM. This is still work in progress, however.

In Tunisia, the Prime Minister issued a circular on 27 May 2011 concerning the quality of legislation that considers the effectiveness of legal texts and provides for impact assessment studies to be carried out as part of the drafting of laws on commercial, financial and social matters. Financial studies incorporate both the cost and the impact on financing options (OECD, 2013). In practice, the circular has not been implemented in a systematic and effective manner across 
government. Many draft legislative acts have been submitted to the CoM and parliament without such documentation in the past few years. More recently, a government circular issued in November 2017 clarified guidelines and documents that should accompany draft legislation submitted to the council of ministers and parliament, with no specific mention of impact assessments.

In conclusion, openness in the planning process was not accompanied by a structured consultation process. Additionally, while the governments do from time to time conduct some form of consultation, the results are not dealt with systematically or in a transparent manner. Also, feedback is not shown to be taken systematically into consideration or to alter the original lines of the legislation to provide alternatives and different scenarios.

\subsection{FINANCIAL COST OF LEGISLATION}

The direct financial cost of implementing legislation is the impact on the budget. This has several aspects. First, there is the increased cost of administration, e.g. increases in the number of civil servants, with financial implications on the wage bill, allowances, and pensions. Another aspect appears in case the legislation provides for grants or exemptions for households or business. Also, it may have implications on the public investment program, like new buildings and construction. Additionally, it may entail more purchase of goods and services. Impact on deficit and financing options through borrowing is another dimension. Transfers and subsidies could be impacted as well from the new legislation.

All these impacts should be assessed during the process of law making. Therefore, if this process is not strong enough, this may create unforeseen impacts on the budget; especially in case of out of budget decisions such as labor compensation and interest payments, in addition to socially politized items such as transfers to the households. The international experience identifies a seven-step process for a normal piece of legislation. It starts with preliminary drafting in the relevant government agency, sharing internally among government agencies, consultations with external bodies, passing it to the Council of Ministers (CoM), the parliamentary process, and promulgation by the President and finally reviews the impact. Table A3 presents some remarks on this process in the country case studies. When the step is compound, we add the financial impact assessment (FIA) in brackets as additional information for clarification.

In Jordan, a Prime Ministerial directive instructed all line ministries to establish a legal unit to help in drafting new legislation in terms of providing compelling reasons for a legislation as well as annotations that explain that legislation. But no direct instruction was issued regarding the assessment of regulatory impact. Law no. 56 of 1997 article 3-j stipulates that the MoF give an opinion on draft laws, by-laws, agreements, and any other issues that have a financial impact on the treasury. But again, no guidelines spell out how this impact should be reviewed. In practice, the MoF asks line ministries to provide assessment of proposed 
legislations. No legislation supports MoF in its demand of data from line ministries. On external consultation, a Royal Decree (207) and the Constitution (article 120) established the Economic \& Social Council. It has to advise on all items of legislation before passing them. Its 45 members are appointed by the King to represent all groups of the society. It is independent of the executive branch of the government. However, no guidelines were produced to structure the process of RIM or to assess the financial dimension. MoF has permanent representative at LOB to review any draft law that entails a financial impact.

Similarly, in Egypt, the CoM issued instructions in June 2018 for all government agencies to establish as part of its organizational structure, units for legislative support including assessing the impact thereof. By law (Organic Budget Law No. 53 of 1973, \#27) all government agencies should alert the MoF if they propose any legislation (even for new administrative instructions) that may have a financial impact. But there are no guidelines to structure the process, so far, it is up to the discretionary assessment of government agencies. Additionally, it is discretionary and left to the government agency proposing the legislation. Guidelines on how to structure this assessment were overlooked. Unless, the law has a major financial impact in the short run, the MoF prefers to investigate the impact through the process of the budget preparation. External consultation before Cabinet approval on the legislation is not allowed according to the guidelines of the Ministry of Justice for drafting laws (Ministry of Justice, 2018). Sometimes the Parliament conducts discretionary consultation sessions when the legislation affects the business community. Recently in 2016, Parliament established a staff training center, where RIA is one of the training subjects. The pertinent Plan and Budget Committee (PBC) rarely requests the government to provide budgetary impact assessments for legislation or request alternative policies rather than those embedded in the proposed laws.

Tunisia has, de jure, a different framework. The circular No.14 requires government units to conduct impact assessment on draft laws, including a financial assessment. In practice, a limited number of laws have applied the RIA system. Ministries sponsoring legislation are required to submit draft laws that entail a direct impact on the budget to the ministry of finance for consultation. However, there is no clear guideline on whether a financial impact assessment is required to be submitted for that consultation process.

In the three countries, the approval of the parliament is mandatory to enact the legislation. Then the head of the State issued it to be published in the Official Gazette. The sequence presented by table A3, shows the process RIA application is developing, yet, it is weak for FIA. Moreover, the role of the MoF is not strong enough in the process of drafting. As interviews for Egypt indicated, the soft or weak roles of finance central agencies (MoF and Planning ministries) delay the identification of most of the financial impact to the budget exercise. This may come too late for other options that could be considered in the stages of drafting 
or discussion in the $\mathrm{CM}$ or the parliament to be reviewed and revisited. Besides, when the executives present some information on the financial cost of the legislation, it was observed that it takes the form of the standard costing. Benefit-cost analysis and efficiency analysis are missing or incomplete in most cases. This limits the ability of the public and the parliament, as well as the CoM, to review the effectiveness and efficiency of the legislation, and hence to consider other alternatives and options. Benefit/cost analysis is being increasingly widely adopted as the formal methodological requirement underpinning RIA within OECD countries (OECD, 2009). In those countries that consider the financial impact assessment, cost benefit assessment is widely conducted, however, in some of them they combine it with cost effectiveness especially when the law targets issues related to public health and safety.

In our case studies, while there is no mandatory rule to conduct the assessment except in Tunisia, in a few cases we tracked governments presenting the standard cost of implementing the proposed law. In Egypt, the MoF presents the financial impact of any fiscal law. This impact shows the annual flow of expenses or revenues as of the full implementation of the legislation. While the Macro Fiscal Unit in the MoF performs an assessment of this on the fiscal sustainability, it is not always presented in the law memorandum to the parliament. This means that the impact of the law making on the future budgeting exercise is not well discussed. For sectoral laws, the MoF and the Ministry of Planning and Administrative Development (MoPAD) are invited sometimes on a discretionary basis to contribute to the process of preparing sectoral strategies and laws to tap up ahead the financial cost and to inform the budget preparation process. Yet, the standard practice is that the MoF and MoPAD are informed about the new proposed laws (and the strategy) through the cabinet, as all sectoral strategies and proposed draft laws should be presented to the cabinet for consideration and approval for them to be passed to the parliament. There is no process by law or practice in Egypt according to which the line sectoral ministry shares its strategy with the parliament or the parliament has the role of endorsing the sectoral polices if they are not part of some piece of legislation.

Moreover, when the executive branch of the government supplements the proposed law with FIA, the Plan and Budget Committee (PBC) has to be the main committee entitled for discussing these assessments besides the sectoral committees. Many of the Egyptian laws were presented without FIA and hence the PBC was not present in the discussions with the sectoral specialized committee on the subject matter. Moreover, the role of the PBC during the period (2001-2018) was very limited, i.e. it was not included in the referral decisions most of the times, with limited participation in the others. Further, the FIA was not fully conducted, covering only the law's ratification year without any long-term prospects ${ }^{1}$. However, the burden of weak financial RIA is critical. For example, the annual bill of

\footnotetext{
${ }^{1}$ Based on a content analysis conducted by the authors regarding the law enacted in Egypt's parliaments during the stated period.
} 
a retroactive increase in pension allowances comes to 50 billion Egyptian pounds. Additionally, the state budget draft for FY 2018/2019 allocates 1.9 billion Egyptian Pounds to pay the cash allowance for regular leave that the employees do not take as an impact from the Law of Civil Service (MoF, Egypt).

In conclusion, this section indicated that MENA countries perform poorly in RIA practices, especially, when it comes to assessing the financial impact of legislations. Little attention is given to the due impact on budgeting work. This raises questions on how parliaments in the region can handle budgeting issues while their knowledge on the impact on fiscal sustainability is minimal. Also, the partial communication with citizens in the process of law-making raises skepticism concerning how the available knowledge on policy impacts and public priorities and preferences informs the law-making process.

\section{SECTION III: THE BUDGET LAW THROUGH A RIA LENS}

The two previous sections revealed that notwithstanding the diminishing fiscal discretion, the financial scrutiny on the impact of proposed laws remains weak. In this section, we delve into the process of making the budget law with the assumption that what is missed in the law-making process may be captured during the budget process.

\subsection{BUDGET REGULATORY IMPACT ASSESSMENT (BRIA)}

Budget law is an interesting example to which to apply the RIA framework. By nature, it is enacted annually by the parliament and promulgated by the head of state. However, it has additional features in that it mirrors all the laws, decrees, and administrative orders in terms of their financial impact. To investigate the budget law through a RIA lens, we need to know the budget law status for the RIA with respect to five dimensions related to transparency, consultation with the public, assessing the impact, accessibility to enacted budget laws, and capacity to review and amend figures in the budget law in future rounds of discussion.

The Open Budget Index (OBI) $)^{2}$ provides answers for 145 questions related to the availability of budgetary data from different perspectives such as the availability and comprehensiveness of budget documents, the role and effectiveness of oversight institutions (legislature and state audit institutions) and budgetary openness. This makes the OBI a rich data set to construct a budgetary RIA (BRIA). We reviewed the questions and sorted them into five sub-indexes, where each of them profiles one of the five dimensions of RIA. Then, we went further into breaking down the sub-index into smaller sub-topics to enrich the analysis. Again, whenever, relevant, we did a third level breakdown to sub- factors. We utilized the

\footnotetext{
${ }^{2}$ The Open Budget Index is produced by the International Budget Partnership (IBP). The OBI assesses the three components of a budget accountability system: public availability of budget information; opportunities for the public to participate in the budget process; and the role and effectiveness of formal oversight institutions, including the legislature and the national audit office. The majority of the survey questions assess what occurs in practice, rather than what is required by law (IBP at: https://www.internationalbudget.org/openbudget-survey/methodology/).
} 
answers of 135 questions to fill in the BRIA, following the methodology of Open Budget Index of aggregating by the unweighted average scoring. Figure A7 shows the BRIA composition and mapping to RIA dimensions.

As figures $\mathrm{A} 8 \mathrm{a}$ and $\mathrm{b}$ show, the BRIA performance varies among regions with observable discrepancies among the same region as demonstrated by table A4. It is observable that MENA is below the worldwide average in the global score of BRIA and in the five sub-indexes, with high discrepancy among its countries.

Figure A8b highlights the dimensions in which regions achieved their best. While there are variations among regions, all of them are doing well in their effort to allow public access to the budget law and its supplements compared to their performance in other dimensions. The variations among regions are attributed to the number of budget documents that are available to the public in addition to the Budget Law itself. These documents include reviews on the budget implementation, the pre-budget statement, citizen budget, and oversight reports (IBP, 2017).

Least achieved in all regions is the effort to solicit results of the consultation with the public. It is interesting to observe that efforts conducted by the executives to provide information during the planning stage of the Budget Law and by legislatures during the discussion in the parliaments, in addition to providing channels for information flows, have higher scores than that of consultations. This raises skepticism about the effectiveness of the transparency and openness efforts if they do not find ways to contribute to the process of law-making.

Compared to other regions, the rank of MENA comes at the end for the dimensions of consultation with the public, conducting impact assessment, and challenging regulations, while the region came second to lowest in two dimensions: transparency and accessing rules and regulations (figure A8b).

Under the dimension of transparency, we can split the efforts conducted by the executives from those of the legislatures (table A5). The same applies for the dimension of soliciting results of public consultations. Worth mentioning that for soliciting the opinion of the public, the legislature's contribution compared to the executive's varies widely among regions, which can be attributed to differences in the political regime and practices. Yet, in MENA, both scores are the lowest worldwide. When it comes to the effort to solicit the results of consultation with the public to feed them into the law-making process, the international experience is skewed to the effort done by legislatures. Yet this role in MENA is completely absent from both the sides of the parliaments and the executives.

To analyze in depth the practice of impact of the budget law, we identified four attributes: availability of financial data, availability of the assumptions based on which the budget figures were produced, availability of data to assess the impact of the budget implementation on different target groups and policies; being new or 
existing, and finally the availability of debt figures and medium-term fiscal outlook to have foresight on fiscal sustainability. Figure A9 reports on the results by region.

It is interesting to see that except in MENA and Sub-Saharan Africa, the level of data availed by the executives to the parliaments is moderate to high. Regarding the availability of financial data, we can differentiate between those related to line items and those for the outcomes of policies to different socio-economic groups (table A6). Legislatures generally are less accurate about the budgetary impact on socio-economic groups, such as the poor, women and private sector. They are more informed about line items and the holistic fiscal trends. The knowledge of the legislatures in MENA about the financial data by line items and policy outcomes is lower than that of all the other legislatures worldwide.

Regarding the openness in sharing the assumptions used to build the budget figures, all regions showed low performance. Again, this raises some doubts about the quality and meaningfulness of assessments performed by the parliaments or the public where the assumptions underpinning the law-making of the budget are not fully shared. It is also interesting to observe that except for high income OECD countries, the capacity of legislatures to track the impact of the Budget Law on existing and new policies is relatively low. Finally, the availability of debt figures to conduct risk assessments is relatively acceptable across regions, right after the availability of financial data.

Zooming in on our case studies, their BRIA scores are 43.9, 42.4, and 34.1 for Jordan, Egypt and Tunisia, respectively. This means that they are among the best performers in the region; compared to the low average score of MENA which stands at 18.1. As shown by figure A10, the three countries are in a proximately high status regarding providing the public with means to access the enacted budget law and its supplementary documents. Yet, they cluster around the status of moderate for conducting impact assessment for the budget law. They differ considerably in terms of data availed to the public in the planning and discussion stages, where Egypt scores the highest. None of them solicited the results of consultations with the public into feedback to the process of making the Budget Law.

The sub-index of challenging the trends and content of the Budget Law, reveals discrepancies in the capacities of the public and the legislatures to review and amend the budget law in next budget rounds, Jordan coming out top. Thanks to its massive reform in the subsidy component in the budget, its BRIA score in this dimension levelled high.

From our micro analysis, we can tell that the legislatures in the three cases do not initiate any review of the budgetary figures. However, those changes cannot be implemented without being enacted by the legislatures. Therefore, we expect that Egypt's score in the new round of OBI will go up with all the amendments introduced in the energy subsidy component in the budget during 2017/18. 
Based on this, one could argue that the three countries are doing well in terms of BRIA, which could be consistent with their RIA scores shown in table A2. Yet, this is not consistent with tracked weaknesses depicted by the micro analysis for the law-making process especially for its relationship with FIA and the incomplete implementation of the legal decrees issued by their governments. This could be attributed to the methodology of constructing BRIA that uses the unweighted average which made the index skewed towards the extreme factors. Further, our BRIA results do not capture the dependency relationship among different dimensions.

To construct effective transparency indexes, we used a more balanced measure of central tendency ${ }^{3}$ : the geometric mean, with an exception of using the maximum value in some cases. The maximum values were used to deal with what could be named as "parallel alternatives". In compositing some indices there are factors that could be alternatives to each other. In such cases, the maximum value technique was used, to have the highest score among these alternative factors to indicate that the desired objective beyond this index was achieved.

We can explore more the importance of applying geometric means by recalling the example we provided above on the meaningless of one-way communicating with the public: availing data on the budget by the executives or the parliament, without soliciting the public feedback into the law-making of the Budget Law. Also, what is the value of providing figures on the budget if the assumptions behind them in addition to other important complementary data are not shared. We think that when there is a value chain and dependency relationship, geometric mean is a much better option than the unweighted average. Accordingly, we used the subdimensions of BRIA and calculated two indexes to capture the effectiveness of transparency taking into account this dependency relationships: one the Effective Transparency of Fiscal Sustainability (ETFS) and another on the Effective Transparency on Policy Targeting (ETPT). The ETFS index covers all the dimensions required for effectively evaluating the transparency of fiscal sustainability data, including: availing related data through proper means of communications with the public and the parliaments as well as the measures to solicit the public opinions. The same applies for ETPT regarding the data, means and measures for both financial and non-financial issues for policy targeting by outcomes. In both indexes, availing meaningful data and openness to public are embedded. Table A7 presents the results by regions.

It is interesting to observe that worldwide, the policy impact of the budget is still given lower importance than the issue of fiscal sustainability. Worth mentioning is that Eastern Europe outperforms Latin America in the fiscal sustainability index,

\footnotetext{
${ }^{3}$ Geometric means is being used when not much attention needs to be paid to the extreme values. In other words, the geometric mean, which was used in Human Development Index (HDI) for example, tries to reduce the influence of the extreme values. This means that geometric average will maintain the positioning of lowperformance or high-performance countries in a case in which they have an extreme high-level factor or lowlevel factor in both cases respectively.
} 
and they exchange positions when it comes to policy targeting. Further, high income countries kept excelling, yet, with relatively lower scores in policy targeting. While results vary significantly within each region, the level of heterogeneity is at its minimum in High Income Countries-OECD. While High Income Countries-OECD are far ahead in the three dimensions, more effort to establish effective two-way communication is still needed (figure A11). It can be said that shortcomings in effective communication are a worldwide issue. Yet, it is the culminating result of overlooking the importance of internalizing the feedback of citizens into the law-making process. It is a key vehicle to enlighten the legislatures to take informed decisions for their societies in a way that fulfils the objectives of the Budget Law.

MENA shows higher heterogeneity in performance for the two indexes of effective transparency than that of BRIA at large. The interesting result is that Jordan outshines Egypt and Tunisia, especially for ETPT, thanks to the recent application of program-based budgeting accompanied by the high level of data availing to the public. Tunisia, while doing much better than Egypt in availing data to the legislature on policies and outcomes, has a means of communicating with the public that is relatively low performing, which pulled down the level of effective transparency to the very low levels shown in table A8.

The use of the geometric means pulls the status of Tunisia's score downward, thereby providing an alert to the unfinished job related to availing the data to the public. For Egypt and Jordan, while they are doing moderately well in the dimension of communicating to the public, their final performance was impacted by the quality and comprehensiveness of data provided for the performance of an impact assessment.

\section{SECTION IV: CONCLUSION AND RECOMMENDATIONS}

The study focused on the budget law, as the overall framework that gathers together all the financial impacts of laws enacted by parliament. Legislatures must apply a comprehensive analytical approach including RIA and FIA when enacting new laws. Ratifying new laws with little scrutiny as to their impact on the budget structure and figures risks wasting scarce resources and jeopardizes the flexibility of the budget to respond to the emerging needs of the citizens. Greater attention should be given to the transparency of the process of law-making in terms of assessing the financial implications and of balancing them against expected benefits using efficiency and effectiveness measures.

The analysis profiled the MENA region in a comparative context that measures regional performances in implementing regulatory impact assessments. The study focused on three specific country cases to deepen the analysis. We found that legislatures in MENA countries are experiencing diminishing fiscal room to influence the allocation of budget resources. In other words, the fiscal democracy index is dramatically low and even negative in some countries. The historical practices of enacting legislation with significant fiscal implications without the 
requisite level of oversight have impacted the budget structure and public debt burden. Most of the budget resources are devoted to meeting mandatory or obligatory expenses. Nevertheless, this challenging situation has not pushed governments into focusing greater scrutiny on the financial implications of new laws through applying the good practices of law-making. Most of the new laws continue to be enacted by parliaments without deep knowledge of standard cost, efficiency and effectiveness measures, let alone the future financial sustainability.

In many of our interviews, officials from the MoFs and members of the parliaments indicated that they postpone the conducting of FIA to a later stage when enacted laws are set into implementation. They perceive the process of budget making as the opportunity to assess in retrospect the FIA of the passed sectoral laws and their embedded policies. They may stretch the implementation of some laws over a longer time span to accommodate their financial impact. That is to say, legislators conduct RIA in retrospect. Additionally, they negotiate the budget requests, reflecting the enacted policies, to control for negative impacts on fiscal sustainability. The study has challenged this practice by scrutinizing the process of making the budget law through a RIA lens. We utilized the rich set of data of the OBI to construct the RIA index that allows screening the process of budget making through the whole steps of law-making, starting with planning and ending with publication in the Official Gazette. MENA did not perform well. Even the moderate scores of the three case studies went down when the analysis shifted to count for balanced performance.

We conclude this study by stressing the responsibility of legislatures to improve the fiscal democracy index. The parliamentary fiscal functions must be operated in an integrated manner. This means that executives should provide information about the financial impact of the proposed laws. The legislatures should also request such an assessment. They have to protect the budget from those financially unassessed laws and policies.

Also, as we built on OBI to establish the budgetary index of RIA, the survey could be utilized as an advocacy tool for conducting RIA. OBI has gained a lot of importance over the years and has acquired advocacy power (de Renzio and Masud, 2011). It could be a good tool to encourage the mentioned responsibilities. Adding a few questions to make sure that each of the executives and legislatures perform their responsibilities for RIA will voice this issue. Additionally, producing indexes for effective transparency would stress the balance that should be attained among different attributes for transparency. The only average measuring of transparency hides critical policy messages.

\section{Disclosure statement}

No potential conflict of interest was reported by the authors. 
TABLES

\section{TABLE A1}

Overall deficit/surplus in MENA Arab countries (2009-2016)

\begin{tabular}{|c|c|c|c|c|c|c|c|c|}
\hline & 2009 & 2010 & 2011 & 2012 & 2013 & 2014 & 2015 & 2016 \\
\hline $\begin{array}{l}\text { Surplus/deficit } \\
\text { (US \$Billion) }\end{array}$ & -46.9 & 7.4 & 94.0 & 139.9 & 67.2 & 53.4 & -213.8 & -234.5 \\
\hline$\%$ GDP & -2.6 & 0.4 & 3.9 & 5.3 & 2.5 & 1.9 & -8.8 & -10.0 \\
\hline $\begin{array}{l}\text { Oil countries }^{4} \\
\text { (US \$ Billion) }\end{array}$ & -22.0 & 36.6 & 127.1 & 182.2 & 118.9 & 100.7 & -185.9 & -191.3 \\
\hline$\%$ GDP & -1.6 & 2.3 & 6.6 & 8.5 & 5.4 & 4.6 & -10.0 & -10.4 \\
\hline $\begin{array}{l}\text { Non-oil } \\
\text { countries } \\
\text { (US \$Billion) }\end{array}$ & -24.9 & -29.2 & -33.1 & -42.3 & -51.8 & -47.3 & -27.9 & -43.1 \\
\hline$\%$ GDP & -5.7 & -6.1 & -7.3 & -8.4 & -9.8 & -8.5 & -4.9 & -8.5 \\
\hline
\end{tabular}

Source: Joint Arab Economic Report, Multiple issues (2014-2017), Arab Monetary Fund.

\section{TABLE A2}

Global indicators of regulatory governance for Arab countries ${ }^{5}$

\begin{tabular}{|c|c|c|c|c|c|c|c|}
\hline & $\begin{array}{l}\text { Publica- } \\
\text { tion of } \\
\text { proposed } \\
\text { text }\end{array}$ & $\begin{array}{l}\text { Conduct } \\
\text { consulta- } \\
\text { tion }\end{array}$ & $\begin{array}{c}\text { Reporting } \\
\text { the consul- } \\
\text { tation } \\
\text { results }\end{array}$ & $\begin{array}{c}\text { Conduct } \\
\text { impact } \\
\text { assess- } \\
\text { ment }\end{array}$ & $\begin{array}{l}\text { Specialized } \\
\text { body for } \\
\text { impact } \\
\text { assessment }\end{array}$ & $\begin{array}{c}\text { Impact } \\
\text { assessment } \\
\text { made } \\
\text { public }\end{array}$ & $\begin{array}{c}\text { Consolidated } \\
\text { regulatory } \\
\text { governance } \\
\text { score }\end{array}$ \\
\hline Algeria & 0 & 0.2 & 0 & 0 & 0 & 0 & 0.2 \\
\hline Bahrain & 0 & 0 & 0 & 1 & 1 & 0.2 & 2.2 \\
\hline Comoros & 0.6 & 0.6 & 0.8 & 0 & 0 & 0 & 2 \\
\hline Djibouti & 0.2 & 0 & 0 & 0 & 0 & 0 & 0.2 \\
\hline Iraq & 1 & 0 & 0 & 0 & 0 & 0 & 1 \\
\hline Jordan & 1 & 0.6 & 0.2 & 0 & 0 & 0 & 1.8 \\
\hline Kuwait & 0.2 & 0.2 & 0 & 0 & 0 & 0 & 0.4 \\
\hline Lebanon & 0 & 0 & 0 & 0 & 0 & 0 & 0 \\
\hline Libya & 0 & 0 & 0 & 0 & 0 & 0 & 0 \\
\hline Mauritania & 0 & 0 & 0 & 0 & 0 & 0 & 0 \\
\hline Morocco & 1 & 1 & 1 & 0 & 0 & 0 & 3 \\
\hline Oman & 0 & 0 & 0 & 0 & 0 & 0 & 0 \\
\hline Qatar & 0 & 0 & 0 & 0 & 0 & 0 & 0 \\
\hline Saudi Arabia & 0 & 0 & 0 & 0 & 0 & 0 & 0 \\
\hline Sudan & 0 & 0 & 0 & 0 & 0 & 0 & 0 \\
\hline Tunisia & 1 & 1 & 0 & 1 & 0 & 0 & 3 \\
\hline $\begin{array}{l}\text { United Arab } \\
\text { Emirates }\end{array}$ & 0.6 & 0.2 & 0.2 & 1 & 1 & 0.2 & 3.2 \\
\hline Palestine & 0.2 & 0.6 & 0 & 0 & 0 & 0 & 0.8 \\
\hline Yemen & 0 & 0 & 0 & 0 & 0 & 0 & 0 \\
\hline
\end{tabular}

Source: Global Indicators of Regulatory Impact Assessment Governance, 2016.

${ }^{4}$ Oil Arab countries are the Arab petroleum net exporting countries and are represented by members of the Organization of the Petroleum Exporting Countries (OPEC), in addition to Iraq, Algeria, Libya, and Yemen (Arab Monetary Fund, 2017).

${ }^{5}$ The scores range from 0 (worst performance) to 5 (best performance). 


\section{TABLE A3}

The law-making process and financial impact assessment (FIA)

FIA in Internal con- External Discussion Parlia- Promulga- Follow-up

Prelimi- sultation consul- and mentary tion by the to the

nary among gov- tation approval by approval head of implemen-

drafting ernmental (FIA) the Council

(FIA) state and tation of agencies on of Ministers

publication the law

FIA (FIA)

\begin{tabular}{|c|c|c|c|c|c|c|c|}
\hline Jordan & Absent & $\begin{array}{l}\text { Consultation } \\
\text { is not manda- } \\
\text { tory by law }\end{array}$ & $\begin{array}{l}\text { Manda- } \\
\text { tory } \\
\text { (Soft) }\end{array}$ & $\begin{array}{l}\text { Mandatory } \\
\text { (Soft) }\end{array}$ & $\begin{array}{l}\text { Mandatory } \\
\text { (Soft) }\end{array}$ & Mandatory & $\begin{array}{c}\text { Discretion- } \\
\text { ary }\end{array}$ \\
\hline Egypt & Absent & $\begin{array}{l}\text { Consultation } \\
\text { is not manda- } \\
\text { tory by law }\end{array}$ & Absent & $\begin{array}{l}\text { Mandatory } \\
\text { (Soft) }\end{array}$ & $\begin{array}{c}\text { Mandatory } \\
\text { (Soft) }\end{array}$ & Mandatory & $\begin{array}{c}\text { Discretion- } \\
\text { ary }\end{array}$ \\
\hline Tunisia & Soft & $\begin{array}{l}\text { Consultation } \\
\text { is not manda- } \\
\text { tory by law }\end{array}$ & Absent & $\begin{array}{l}\text { Mandatory } \\
\text { (Soft) }\end{array}$ & $\begin{array}{c}\text { Mandatory } \\
\text { (Soft) }\end{array}$ & Mandatory & $\begin{array}{l}\text { Discretion- } \\
\text { ary }\end{array}$ \\
\hline
\end{tabular}

Source: authors' analysis.

\section{TABLe A4}

Discrepancy in Budgetary Regulatory Impact Assessment (BRIA) ${ }^{1,2,3}$ performance by region

BRIA Coefficient of Variation (CV), \%

\begin{tabular}{|c|c|c|}
\hline East Asia \& Pacific & 39.4 & 54.0 \\
\hline Eastern Europe \& Central Asia & 39.0 & 31.7 \\
\hline Latin America \& Caribbean & 37.7 & 43.3 \\
\hline Middle East \& North Africa & 18.1 & 105.5 \\
\hline South Asia & 33.7 & 12.5 \\
\hline Sub-Saharan Africa & 21.4 & 77.9 \\
\hline High Income: OECD Countries & 54.8 & 14.2 \\
\hline Grand total & 32.8 & 57.8 \\
\hline
\end{tabular}

1-The unweighted average was used to aggregate the index-value at the regional level.

2-Reference year 2017.

3-The coefficient of variation used was calculated across countries within the mentioned regions.

Source: authors' analysis. 
Legislatures and executives contribution to effectively open to the public ${ }^{1,2}$

Transparency dimension

Consultation dimension

\begin{tabular}{|c|c|c|c|c|c|c|}
\hline \multirow[b]{3}{*}{ Regions } & \multirow{2}{*}{\multicolumn{3}{|c|}{$\begin{array}{c}\text { Transparency dimension } \\
\text { Availing information to the public }\end{array}$}} & \multicolumn{3}{|c|}{ Consultation dimension } \\
\hline & & & & \multirow{2}{*}{$\begin{array}{l}\text { Soliciting } \\
\text { results- } \\
\text { executives }\end{array}$} & \multirow{2}{*}{$\begin{array}{c}\text { Soliciting } \\
\text { results- } \\
\text { legislatures }\end{array}$} & \multirow{2}{*}{$\begin{array}{c}\text { Total } \\
\text { dimen- } \\
\text { sion }\end{array}$} \\
\hline & Executives & Legislature & $\begin{array}{c}\text { Sub- } \\
\text { dimension }\end{array}$ & & & \\
\hline $\begin{array}{l}\text { East Asia \& } \\
\text { Pacific }\end{array}$ & 33.8 & 19.8 & 27.6 & 5.2 & 14.1 & 9.6 \\
\hline $\begin{array}{l}\text { Eastern Europe } \\
\& \text { Central Asia }\end{array}$ & 19.8 & 27.7 & 26.4 & 0.8 & 11.9 & 6.3 \\
\hline $\begin{array}{l}\text { Latin America \& } \\
\text { Caribbean }\end{array}$ & 19.3 & 26.4 & 25.3 & 1.0 & 7.3 & 4.2 \\
\hline $\begin{array}{l}\text { Middle East \& } \\
\text { North Africa }\end{array}$ & 16.4 & 4.9 & 10.5 & 0.0 & 0.0 & 0.0 \\
\hline South Asia & 34.2 & 11.1 & 22.3 & 2.7 & 0.0 & 1.4 \\
\hline $\begin{array}{l}\text { Sub-Saharan } \\
\text { Africa }\end{array}$ & 20.0 & 18.5 & 20.6 & 0.0 & 2.8 & 1.4 \\
\hline $\begin{array}{l}\text { High Income: } \\
\text { OECD Countries }\end{array}$ & 23.5 & 58.3 & 47.4 & 11.6 & 32.4 & 22.0 \\
\hline Grand total & 22.5 & 23.4 & 24.9 & 2.2 & 8.9 & 5.5 \\
\hline
\end{tabular}

1-The unweighted average was used to aggregate the index-value at the regional level.

2-Reference year 2017.

Source: authors.

TABLE A6

Availability of financial data ${ }^{1,2}$

Availability of financial data

\begin{tabular}{|c|c|c|c|}
\hline & Line item data & Program data & Total sub-factor \\
\hline East Asia \& Pacific & 59.5 & 58.9 & 59.5 \\
\hline Eastern Europe \& Central Asia & 71.6 & 55.1 & 63.2 \\
\hline Latin America \& Caribbean & 67.4 & 67.2 & 67.7 \\
\hline Middle East \& North Africa & 27.8 & 21.4 & 24.5 \\
\hline South Asia & 68.3 & 69.8 & 69.5 \\
\hline Sub-Saharan Africa & 33.4 & 26.5 & 29.9 \\
\hline High Income: OECD Countries & 85.8 & 82.9 & 84.7 \\
\hline Sub-factor total & 54.9 & 49.0 & 52.0 \\
\hline
\end{tabular}

1-Unweighted average was used to aggregate the index-value at the regional level.

2-Reference year 2017.

Sources: authors. 
Effective transparency indexes by region ${ }^{1,2,3}$

\begin{tabular}{|c|c|c|c|c|}
\hline & $\begin{array}{c}\text { Effective } \\
\text { Transparency } \\
\text { of Fiscal } \\
\text { Sustainability } \\
\text { (ETFS) }\end{array}$ & $\begin{array}{c}\text { Coefficient } \\
\text { of Variation } \\
(\mathrm{CV}) \\
\%\end{array}$ & $\begin{array}{c}\text { Effective } \\
\text { Transparency of } \\
\text { Policy Targeting } \\
\text { (ETPT) }\end{array}$ & $\begin{array}{c}\text { Coefficient } \\
\text { of Variation } \\
(\mathrm{CV}) \\
\%\end{array}$ \\
\hline East Asia \& Pacific & 11.8 & 163.8 & 10.6 & 139.2 \\
\hline $\begin{array}{l}\text { Eastern Europe \& } \\
\text { Central Asia }\end{array}$ & 10.7 & 123.3 & 9.1 & 123.9 \\
\hline $\begin{array}{l}\text { Latin America \& } \\
\text { Caribbean }\end{array}$ & 10.0 & 156.1 & 10.4 & 155.1 \\
\hline $\begin{array}{l}\text { Middle East \& North } \\
\text { Africa }\end{array}$ & 3.0 & 202.2 & 3.2 & 229.2 \\
\hline South Asia & 3.2 & 184.5 & 4.2 & 107.7 \\
\hline Sub-Saharan Africa & 5.2 & 196.6 & 5.4 & 223.6 \\
\hline $\begin{array}{l}\text { High Income: OECD } \\
\text { Countries }\end{array}$ & 28.2 & 50.2 & 25.0 & 66.5 \\
\hline Grand total & 9.5 & 151.4 & 9.0 & 153.0 \\
\hline
\end{tabular}

1-Unweighted average was used to aggregate the index-value at the regional level.

2-Reference year 2017.

3-The used coefficient of variation was calculated across countries within the mentioned regions.

Sources: authors' analysis.

\section{TABLE A8}

Effective Transparency of Fiscal Sustainability (ETFS) and Effective Transparency of Policy Targeting (ETPT) in Egypt, Jordan and Tunisia

Trans- Public Impact ETFS Trans- Public Impact ETPT parency consulta- assess- parency consulta- assess-

of rule- tion in ment of rule- tion in ment

making rulemak-

making rulemak-

\begin{tabular}{|c|c|c|c|c|c|c|c|c|}
\hline & & ing & & & & ing & & \\
\hline Egypt & 20.8 & 0.0 & 8.6 & 9.8 & 20.8 & 0.0 & 0.1 & 7.0 \\
\hline Jordan & 52.0 & 0.0 & 1.3 & 17.8 & 52.0 & 0.0 & 17.8 & 23.3 \\
\hline Tunisia & 2.7 & 0.0 & 0.4 & 1.0 & 2.7 & 0.0 & 0.4 & 1.0 \\
\hline
\end{tabular}

Source: authors' analysis. 


\section{Figure A1}

General government gross debt ${ }^{6}$ expressed as percentage of GDP by region (2000-2017)

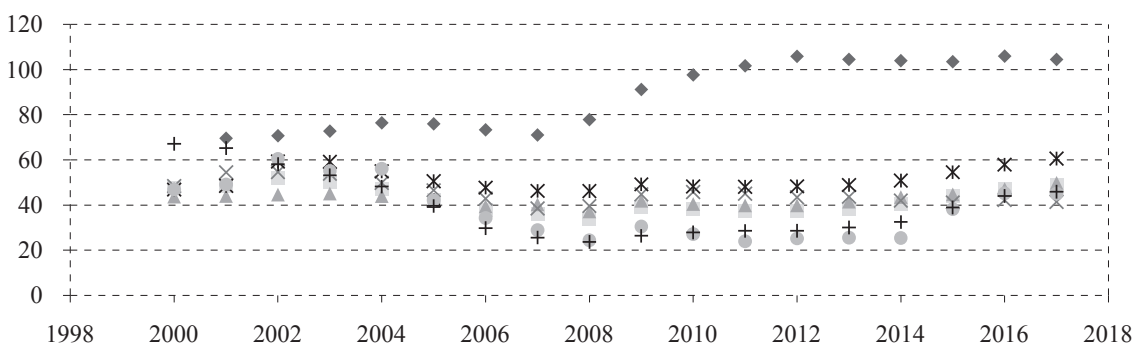

- Advanced economies

$\triangle$ Emerging and developing Asia

* Latin America and the Caribbean

+ Sub-Saharan Africa
Emerging market and developing economies

$\times$ Emerging and developing Europe

- Middle East and North Africa

Source: drawn based on World Economic Outlook (WEO) database, April 2018, International Monetary Fund.

\section{Figure A2}

Dispersion of overall deficit in MENA Arab countries ${ }^{7}$ (2009-2016)

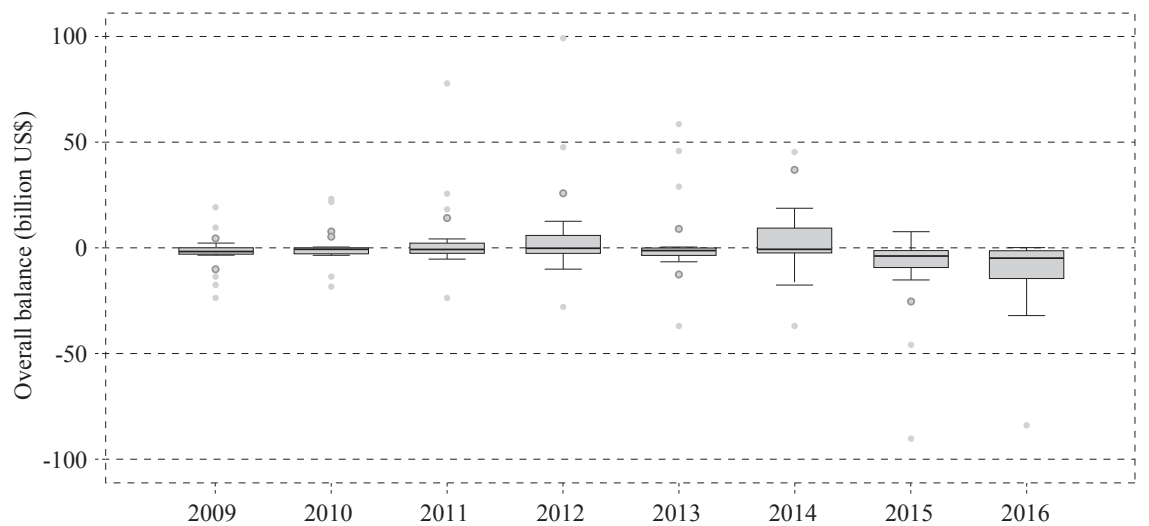

Source: drawn based on Joint Arab Economic Report, Multiple issues (2014-2017), Arab Monetary Fund.

\footnotetext{
${ }^{6}$ General government gross debt consists of all liabilities that payment(s) of interest and/or principal by the central government to the creditor at a date or dates in the future. This includes debt liabilities in the form of SDRs, currency and deposits, debt securities, loans, insurance, pensions and standardized guarantee schemes, and other accounts payable (WEO, April 2018).

${ }^{7}$ A Box and Whisker plot that provides a measure of dispersion of the overall deficit in all Arab countries over the stated period. This chart is not concerned with the individual performance of each Arab country. The upper and lower limits of the boxes represent the upper and lower quartiles, so the box spans the interquartile range whereas the horizontal line crossing the box represents the median, and finally the two lines outside the boxes represent the highest and lowest values of the overall deficit in Arab countries.
} 


\section{Figure A3}

Jordan, Egypt, and Tunisia performance in fiscal democracy index (2010-2017)

(a) Without subsidies ${ }^{8}$

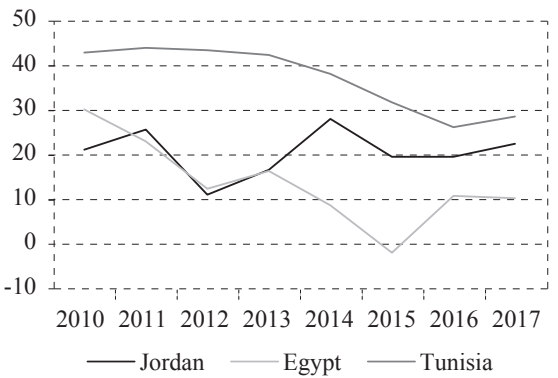

(b) With subsidies ${ }^{9}$

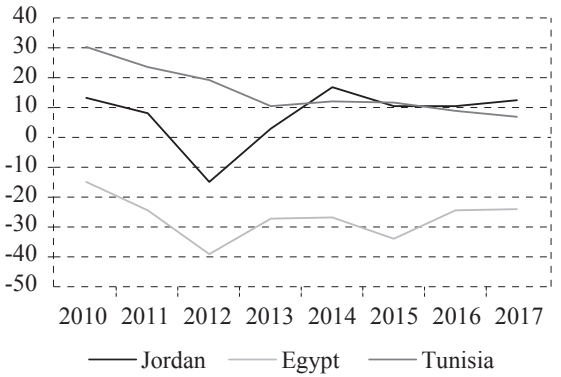

Source: authors' calculations.

\section{Figure A4}

Nominal growth ${ }^{10}$ of the components of government spending in Jordan, Egypt, and Tunisia (2010-2017), \%

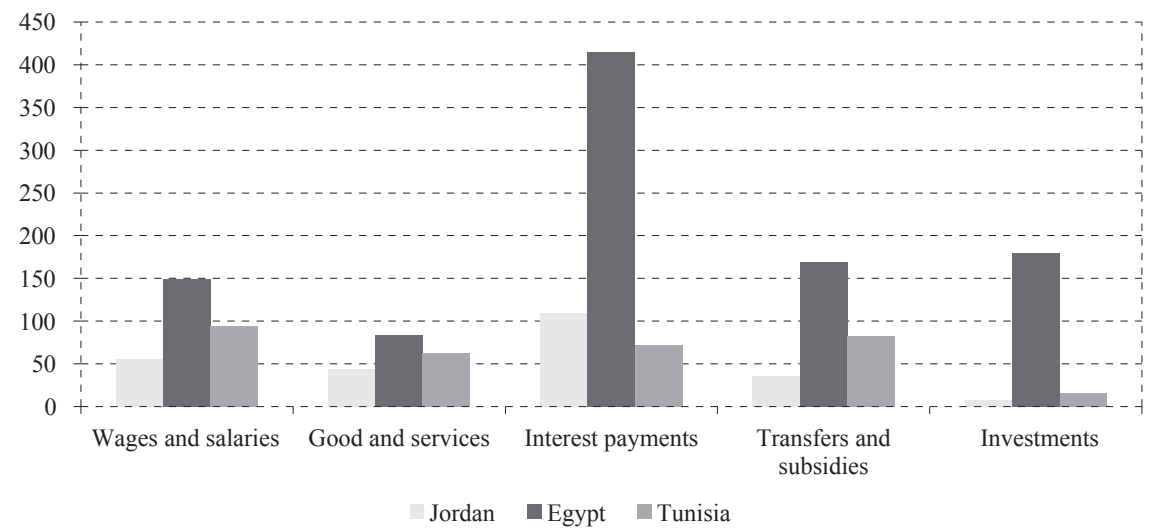

Source: Ministry of Finance, Egypt; Government Budget Department, Jordan; Ministry of Finance Portal, Tunisia.

\footnotetext{
${ }^{8}$ The formula for the index is, ]1- (Mandatory Spending/ revenues) [100; where Mandatory Spending equals spending on wages and salaries, pensions, and interest payments.

${ }^{9}$ In Fiscal Democracy Index with subsidies, subsidies are added as one of the government mandatory spending. ${ }^{10}$ Nominal growth refers to the percentage change in the components of public spending in the ending period (year 2016) compared to the beginning period (year 2010).
} 


\section{Figure A5}

Debt trends in Egypt, Jordan and Tunisia (2010-2017)

(a) General government gross debt ( $\%$ of GDP)

(b) Debt service (\% of total expenditure)
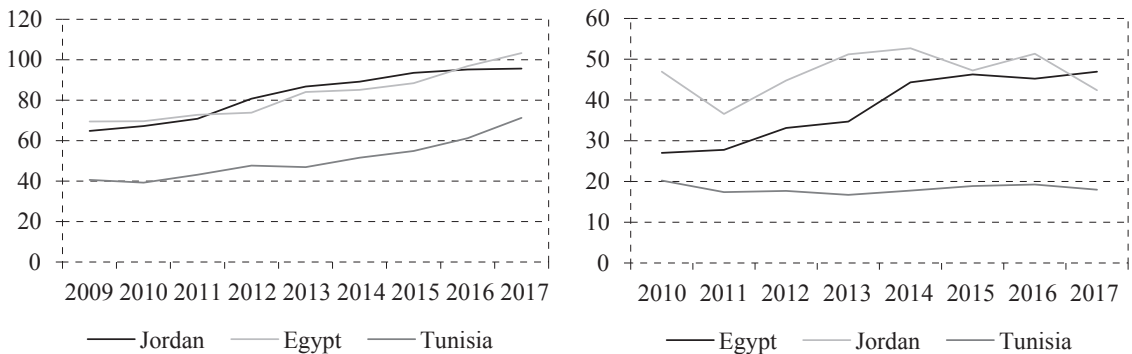

Source: (a) IMF (2018).

(b) MoF.gov.eg. (2018); Ministry of Finance Portal, Tunisia.

\section{Figure A6}

\section{RIA indicators by regions}

(a) Regulatory governance score ${ }^{11}$

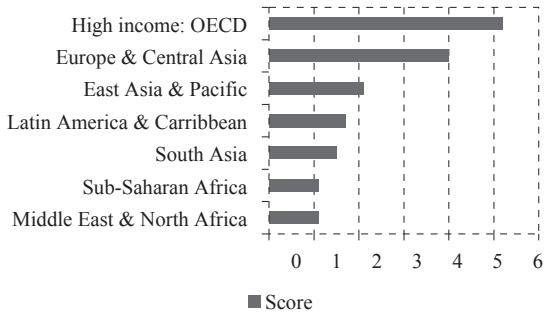

(c) Public comments on proposed regulations are requested

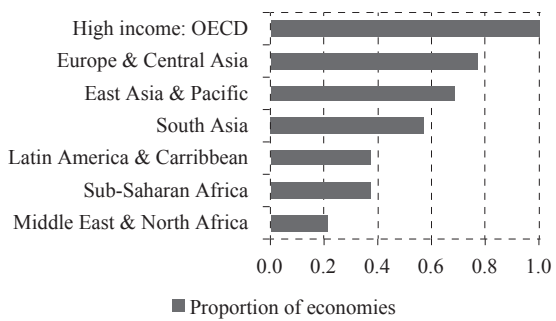

(b) Transparency of rulemaking, ${ }^{12} \%$

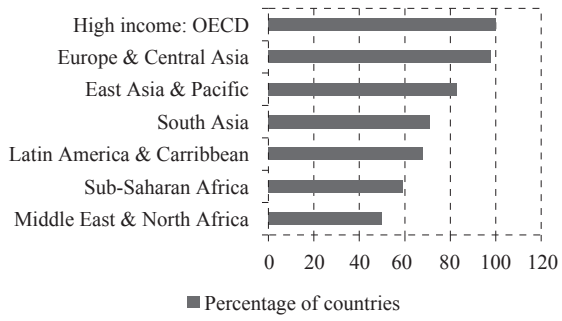

(d) Conduct regulatory impact assessment

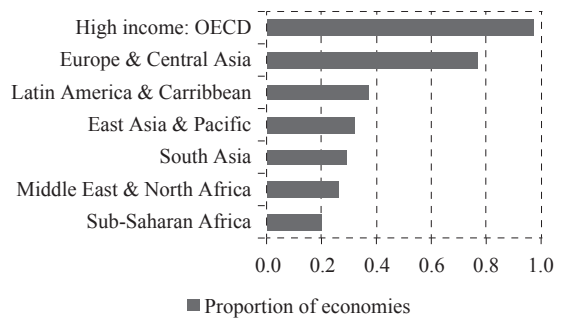

Source: calculated based on Global Indicators of Regulatory Governance, 2016, World Bank.

\footnotetext{
${ }^{11}$ Regulatory Governance Score captures how policymakers interact with stakeholders when shaping regulations affecting business communities. Concerned stakeholders could be professional associations, civic groups or foreign investors. The score ranges from 0 (worst performance) to 5 (best performance) (World Bank, 2018). ${ }^{12}$ Transparency of rulemaking is one of the sub-indices of the Global Regulatory Governance Index. This subindex is concerned with whether regulators commonly communicate with the public about proposed regulations, and if so, how. Communication could be through unified websites where all (or substantially all) new regulations are posted before adoption, websites specific to particular ministries, public gazettes, federal journals or targeted outreach to specific stakeholders (World Bank, 2018).
} 


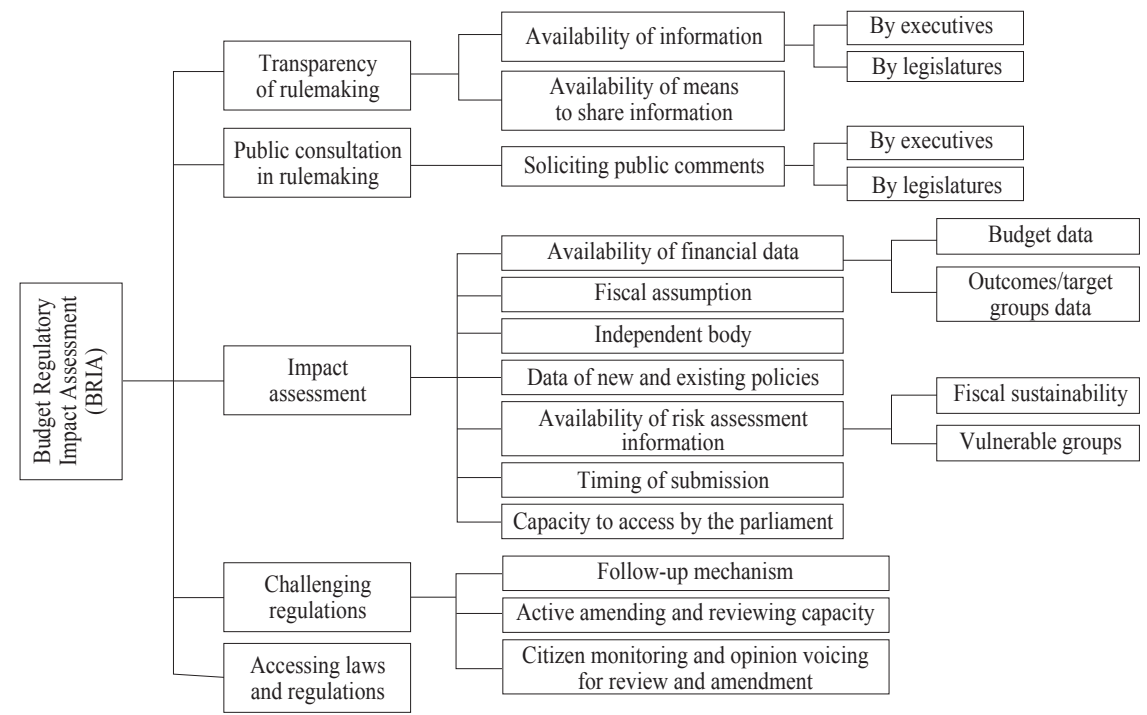

Source: authors' analysis.

\section{Figure A8}

BRIA by region

(a) Consolidated BRIA ${ }^{1,2}$ scores by region

High income: OECD countries

East Asia \& Pacific

Eastern Europe \& Central Asia

Latin America \& Caribbean

South Asia

Grand total

Sub-Saharan Africa

Middle East \& North Africa

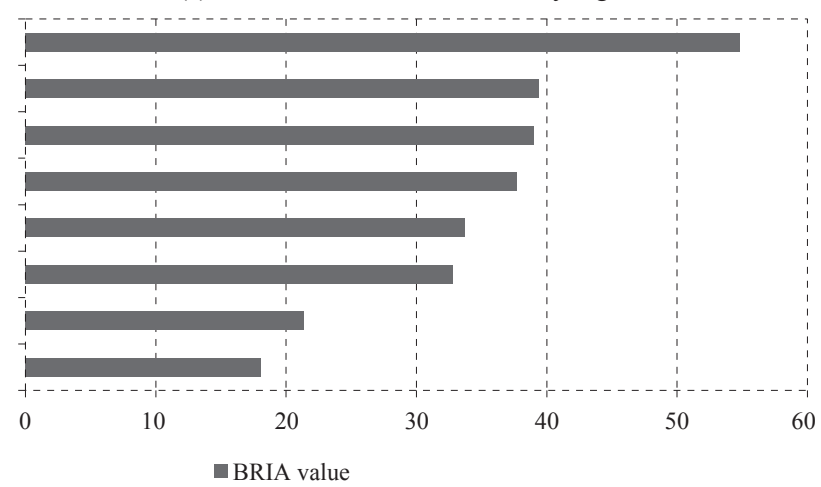

1-Unweighted average was used to aggregate the index-value at the regional level.

2-Reference year 2017.

Source: authors' analysis. 


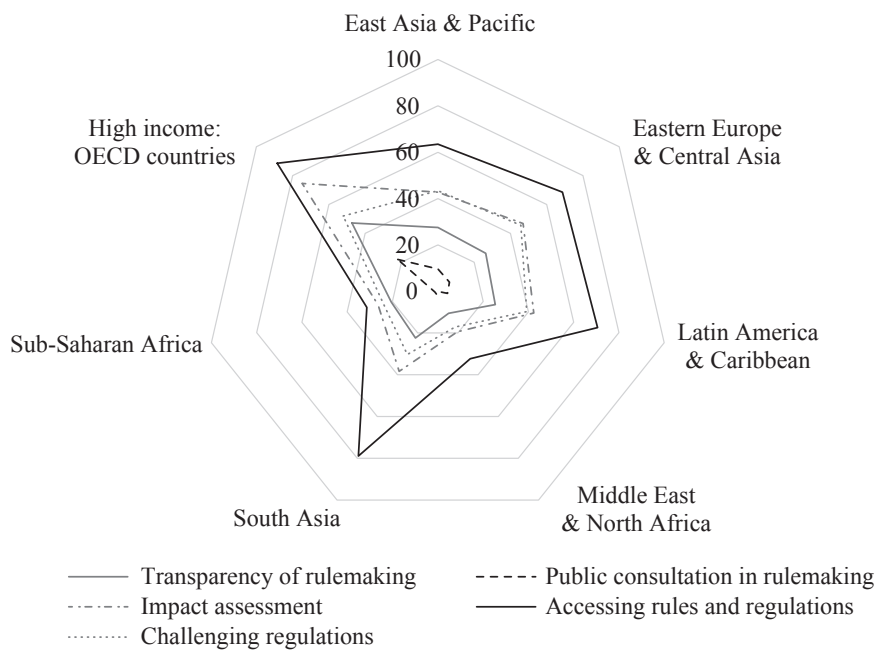

Source: authors' analysis.

\section{Figure A9}

BRIA: impact assessment attributes by region

East Asia \& Pacific

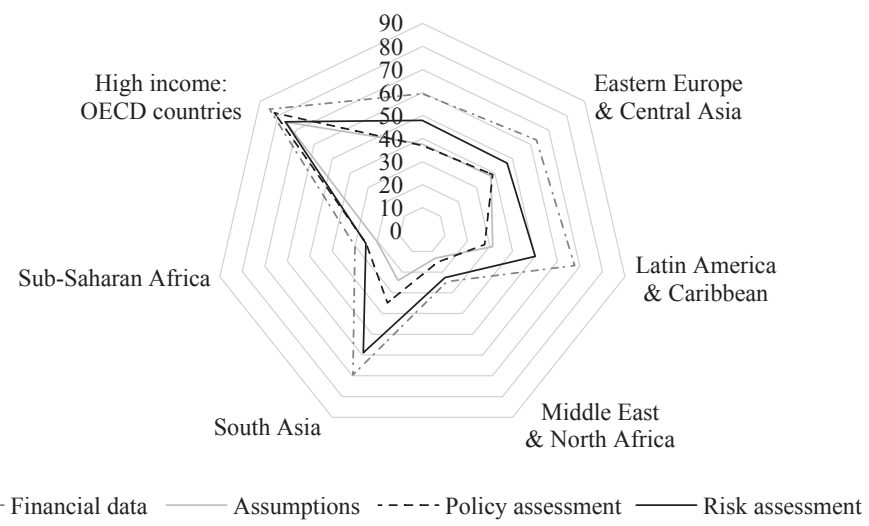

Source: authors' analysis. 
Figure A10

BRIA score for the case studies

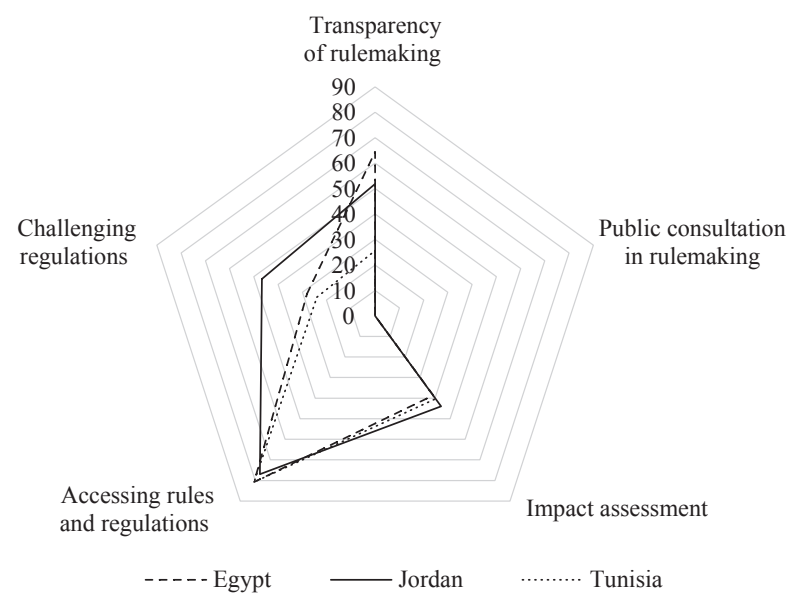

Source: authors' analysis.

\section{Figure A11}

Effective Transparency of Fiscal Sustainability (ETFS) and Effective Transparency of Policy Targeting (ETPT) sub-dimensions by region

(a) ETFS

East Asia

\& Pacific

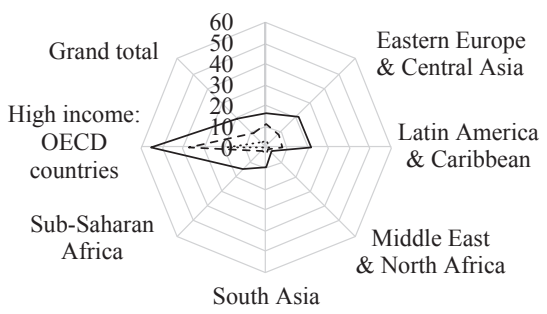

(b) ETPT

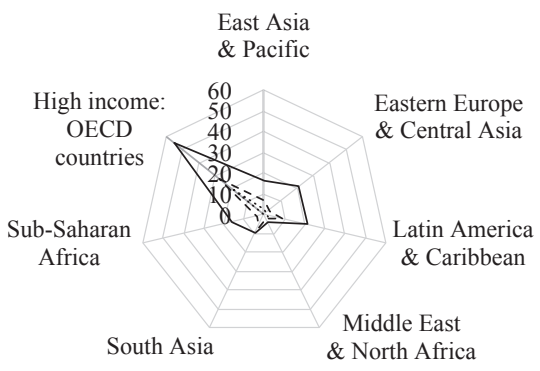

— Transparency of rulemaking Public consultation in rulemaking

- - - - Impact assessment

Source: authors' analysis. 


\section{REFERENCES}

1. Alesina, A. and Perotti, R., 1996. Fiscal Discipline and the Budget Process. The American Economic Review, 86(2), pp. 401-407.

2. Alt, J. E. and Lassen, D. D., 2003. The political economy of institutions and corruption in American states. Journal of Theoretical Politics, 15(3), pp. 341365 .

3. Amf.org.ae., 2018. The Arab Monetary Fund Releases the Briefed English version of The Joint Arab Economic Report (JAER), 2017. Abu Dhabi: Arab Monetary Fund.

4. Austin, D. and Levit, M. R., 2012. Mandatory Spending Since 1962. CRS Report for Congress. Congressional Research Service.

5. de Renzio, P. and Masud, H., 2011. Measuring and Promoting Budget Transparency: The Open Budget Index as a Research and Advocacy Tool. Governance, 24(3), pp. 607-616. https://doi.org/10.1111/j.1468-0491.2011.01539.x

6. de Renzio, P. and Wehner, J., 2017. The Impacts of Fiscal Openness. The World Bank Research Observer, 32(2), pp. 185-210. https://doi.org/10.1093/ wbro/lkx004

7. ERRADA, 2011. Egyptian RIA Guidelines Working document V.7. Egyptian Regulatory Reform and Development Activity.

8. Harrison, T. and Sayogo, D., 2014. Transparency, participation, and accountability practices in open government: A comparative study. Government Information Quarterly, 31(4), pp. 513-525. https://doi.org/10.1016/j.giq.2014.08.002

9. IBP, 2017. Open Budget Survey 2017 Global Report.

10. IMF, 2018. World Economic Outlook Database April 2018. Washington: International Monetary Fund.

11. Jp.gov.eg., 2018. Design of Legislative Guide. Tokio: Government of Japan.

12. Kellerman, A., 2008. Guidelines on Quality of EU Legislation and its Impact on Albania. Eur. JL Reform, 10, 183.

13. MoF.gov.eg., 2018. State Budget. Cairo: Ministry of Finance.

14. OECD, 2009. Determinants of Quality in Regulatory Impact Analysis In: Regulatory Impact Analysis: A Tool for Policy Coherence. Paris: OECD.

15. OECD, 2013. Regulatory Reform in the Middle East and North Africa: Implementing Regulatory Policy Principles to Foster Inclusive Growth. Paris: OECD.

16. Rose, R., 1990. Inheritance before choice in public policy. Journal of theoretical politics, 2(3), pp. 263-291.

17. Sarr, B. and Friedman, J., 2016. Achieving Sufficient Levels of Budget Transparency. Washington: IBP.

18. Shah, A. (ed.), 2007. Budgeting and budgetary institutions. The World Bank.

19. Steuerle, E., 2016. Restoring Fiscal Democracy. Urban.org.

20. Streeck, W., 2010. An Index of Fiscal Democracy. MPIfG Working Paper, No. 10/3. https://doi.org/10.2139/ssrn.1817772 
21. Williams, A., 2015. A global index of information transparency and accountability. Journal of Comparative Economics, 43(3), pp. 804-824. https://doi. org/10.1016/j.jce.2014.10.004

22. World Bank, 2016. Global Indicators of Regulatory Governance. Washington: The World Bank.

23. Zucolotto, R. and Teixeira, M., 2014. Budgetary Transparency and Democracy: The Effectiveness of Control Institutions. International Business Research, 7(6), pp. 83-96. https://doi.org/10.5539/ibr.v7n6p83 